\title{
Scientific approaches to deriving liquid organomineral fertilizers
}

K.S. Artemyeva ${ }^{1}$, postgraduate student

NSC "Institute for soil science and agrochemical researches named after Sokolovskiy"

The purpose. To develop a method of deriving of liquid organomineral fertilizer with the use of local sources of raw materials. Methods. Laboratory-analytical, modelling. Results. Technological approaches to processing local raw materials into organomineral fertilizers with specific content of nutrients are offered. Conclusions. The offered method of deriving liquid organomineral fertilizer is founded on application of accessible organic and mineral raw materials which during transformation get the water-soluble form balanced by the content of humic matters and nitrogen.

Key words: organomineral fertilizers, carbamide-ammonium nitrate, humic acids, humate, extraction, water-soluble complexes.

Introduction. Today, in the conditions of constant increase of prices for mineral fertilizers and deficit of organic fertilizers in the regions of Ukraine where there are natural reserves of organic raw materials (peat, leonardite, brown coal, sapropel), actively implement technologies of production of organo-mineral fertilizers (OMF) with the inclusion of humic acids [1]. It was researched [2-4] that humic acids obtained from raw materials of organic origin by the method of extraction have fertilizer-stimulating properties. During their obtaining, it is crucial to establish optimal extraction conditions, which are determined by removing from the organic raw material the maximum amount of humic and fulvic acids and the minimum possible number of ballast substances, which complicate the process of obtaining preparations [5-7]. The application of such technology elements reduces the rates of mineral fertilizer application, and local raw materials are fully involved in agriculture.

The purpose of the research is to obtain a new type of fertilizer based on carbamide-ammonium nitrate (CAN) and humates balanced on the content of humic substances and nitrogen.

Research methodology. Experimental researches were carried out during the years 2014-2017 in the laboratory of organic fertilizers and humus NSC "Institute for soil science and agrochemical researches named after Sokolovskiy" (certificate of conformity of the measurement system to the requirements of DSTU ISO 10012: 2005 №. 01-0104 / 2017). Agrochemical evaluation of local raw materials with the definition of the quality of organic components, mineral fertilizers and liquid OMF was carried out according to current normative documents.

As a nitrogen-containing component during the preparation of liquid OMF, a $32 \%$ solution of KAS was used containing three forms of nitrogen: ammonium $10.78 \%$, nitrate $11.27 \%$, and amide $10.53 \%$; pH 6.5-7.0. Organic components used humic substances - humates of potassium, with a content of salts of humic acids $45 \mathrm{~g} / \mathrm{l}$, obtained by extraction of humic substances from organic raw materials of various types of peat.

Results and discussion. A series of model-technological experiments was conducted, aimed at, firstly, improving the process of extraction of humic acids from stabilized organic matter to increase the concentration of humates, factors influencing the removal of humic acids: the extractant, duration of infusion, temperature, volume ratio extractant to the mass of raw materials; secondly, the expediency of enrichment of soluble forms of mineral fertilizers obtained by humates during the creation of liquid OMF was substantiated.

The method of obtaining liquid OMF involves the preparation of humates by extraction of potassium alkaline humic substances from low-grade peat to a humidity of up to $75 \%$. For experimental work, five samples of peat from different fields containing humic acids from 55,8 to $97,2 \mathrm{~g} / \mathrm{kg}$, humus substances from 78,1 to $149,5 \mathrm{~g} / \mathrm{kg}$ (Table 1 ) were used.

It was established that humic acids of peat on composition and structure are close to humic acids of soil, therefore plants react quickly to their application [8,9]. According to these basic indicators, selected peat was used for the extraction of humic acids.

\footnotetext{
${ }^{1}$ Scientific supervisor- Skrylnik Ie.V., Doctor of Science of agrarian science
} 
Organic raw materials were pre-crushed and treated with $0.5 \mathrm{n}$ potassium meal solution in a ratio of substance to improve the interaction with the extractant: a solution of extractant (1:10). Extraction lasted 1-2 hours of intense mixing, the temperature of the reaction was no more than $60-80^{\circ} \mathrm{C}$. The solution obtained after extraction was neutralized to $\mathrm{pH} 10-13$ (sulfuric acid, nitric or phosphoric acid) and centrifugation at a rate of $3000 \mathrm{rpm}$. for 15 minutes followed by filtration.

\section{Composition of organic matter of peat}

\begin{tabular}{|c|c|c|c|c|c|}
\hline \multirow{2}{*}{ Characteristics } & \multicolumn{5}{|c|}{ Actual content in raw materials } \\
\hline & peat 1 & peat 2 & peat 3 & peat 4 & peat 5 \\
\hline Mass fraction of moisture, $\%$ & 63,10 & 72,87 & 72,80 & 71,06 & 66,49 \\
\hline Mass fraction of organic matter, $\mathrm{g} / \mathrm{kg}$ & 757,5 & 920,0 & 885,0 & 882,5 & 857,5 \\
\hline Mass fraction of humic acids, $\mathrm{g} / \mathrm{kg}$ & 97,2 & 76,5 & 63,9 & 63,9 & 55,8 \\
\hline Mass fraction of fulvic acids, $\mathbf{g} / \mathbf{k g}$ & 52,3 & 31,5 & 31,7 & 27,5 & 22,3 \\
\hline Mass fraction of humus substances, $\mathrm{g} / \mathrm{kg}$ & 149,5 & 108,0 & 95,6 & 91,4 & 78,1 \\
\hline $\begin{array}{l}\text { Mass fraction of humic acids in organic } \\
\text { matter of peat, } \%\end{array}$ & 13 & 8 & 7 & 7 & 6 \\
\hline
\end{tabular}

Under conditions of observance of technological data, manufactured humates contain from 6 to $10 \%$ salts of humic acids and from 2 to $5 \%$ of salts of fulvic acids. The highest yield of saline of humic and fulvokilot was obtained using peat 1 with an organic content of $757.5 \mathrm{~g} / \mathrm{kg}$ and a moisture content of $63 \%$ (Table 2).

\section{Composition of humates after extraction, $\%$}

\begin{tabular}{|l|l|l|l|l|l|}
\hline \multirow{2}{*}{ Characteristics } & \multicolumn{4}{|l}{ Actual content in solution } \\
\cline { 2 - 6 } & peat 1 & peat 2 & peat 3 & peat 4 & peat 5 \\
\hline $\begin{array}{l}\text { The mass fraction of carbonic humic acids } \\
\text { (Cha) in total carbon (Ct). }\end{array}$ & 68 & 74 & 70 & 73 & 75 \\
\hline $\begin{array}{l}\text { Mass fraction of carbon fulvic acid (Cfa) in } \\
\text { total carbon (Ct). }\end{array}$ & 32 & 26 & 30 & 27 & 25 \\
\hline Mass fraction of salts of humic acids & 9,72 & 7,65 & 6,39 & 6,39 & 5,58 \\
\hline Mass fraction of salts of fulvic acids & 5,23 & 3,15 & 3,17 & 2,75 & 2,23 \\
\hline Mass fraction of salts of humus substances & 14,95 & 10,80 & 9,56 & 9,14 & 7,81 \\
\hline
\end{tabular}

The final stage of the technological process of obtaining liquid OMF is the proportional enrichment of CAN $\left(\mathrm{N}_{32}\right)$ with humus-based preparations up to $15 \%$ to the volume of CAN, which increases the fertilizingstimulating effect and allows the production of water-soluble liquid nitrogen-containing fertilizers with improved agrochemical properties (Table 3 ).

\section{Agrochemical characteristic of indicators of quality of liquid OMF}

\begin{tabular}{|l|l|l|}
\hline \multicolumn{2}{|l|}{ Characteristics } & Actual content \\
\hline \multirow{3}{*}{ The mass fraction } & amid nitrogen, N-NH2,\% & 10,57 \\
& ammonia nitrogen, N-NH4,\% & 10,78 \\
& nitrate nitrogen, N-NO3, \% & 11,27 \\
\hline \multicolumn{2}{|l|}{ Nitrogen content by active ingredient,\% } & 32,62 \\
\hline \multirow{5}{*}{ The mass fraction } & total carbon, Ct, \% & 0,41 \\
& carbon humic acid, Cha, \% & 0,29 \\
& carbon fulvic acid,Cfa, \% & 0,12 \\
& carbon humic acid (Cha) y (Ct), \% & 71 \\
\hline $\mathrm{pH}_{\mathrm{KCl}}$ & salts of humic acids, g/ kg & 5,20 \\
& salts of fulvic acids, g/ kg & 2,50 \\
\hline
\end{tabular}


The resulting liquid OMF is balanced by the content of humic substances and nitrogen, prolonged action. Where combined organo-mineral components reproduce water-soluble complexes available to plants, and dosage takes into account the needs of crops in the nutrition elements.

The advantages of the resulting liquid organo-mineral fertilizers are:

1. Water solubility of fertilizers provides the availability of nutrients to plants and their assimilation at different stages of organogenesis.

2. Provision of plants with nitrogenous nutrition.

3. Growth stimulating effect due to high content of carbon humic acids.

\section{Conclusion.}

The resulting liquid OMF in its composition has a certain amount of nitrogen and humic substances, which are in the form available for plants. Liquid OMF can be used for root nutrition for direct introduction into the soil and in the non-root nutrition.

\section{Bibliography}

1. Vakal S.V., Skryilnik E.V. (2007). Receiving mineral fertilizers with a sodium humate. Radostim. K. 2007. C. 105-106.

2. Cavani L., Ciavatta C., Gessa C. (2003). Identification of organic matter from peat, leonardite and lignite fertilizers using humification parameters and electrofocusing. Bioresource Technology 86. P.45-52.

3. Francioso O., Ciavatta C., Montecchio D. (2003). Quantitative estimation of peat, brown coal and lignite humic acides using chemical parameters, 1H-NMR and DTA analyses. Bio-resource Technology 88. 2003. P.189-195.

4. Francioso O., Sanchez-Cortes S., Tugnoli V. (2001). Spectroscopic study (DRIFT, SERS, 1H-NMR) of peat, leonardite and lignite humic substances. Journal of Molecular Structure 565-566. 2001. P.481-485.

5. Skrilnik E.V., Batsula O.O., Karpach K.S. (2000). Improvement of methods of extraction of humus substances from organic fertilizers. VIsnik HDAU0. № 1. C. 48-53.

6. Nebbioso A., Piccolo A. (2011). Basis of a Humeomics Science: chemical frac-tionation and molecular characterization of humic biosup restructures. Biomacromolecules. №12.-P. 1187-1199.

7. Skrilnik E.V. (2008). Methodological and technological aspects of creating biostimulants of organic origin: collection. mater conf. "Achievements and prospects of the use of humic substances in agriculture". D. 2008. C. $110-112$.

8. Muter O., Limane B. , Strikauska S. (2015). Effect of humic-rich peat extract on plant growth and microbial activity in contaminated soil. Science and Applied Chemistry. №32. P. 68-74.

9. Yakimenko O.S. (2010). Chemical structure and properties of industrial humates of various origin: Sb.mater.conf. "Humic substances and phytohormones in agriculture". D. P. 48-50.

10. Korniyenko Ya.M. Protses vyluchennya huminovmisnykh rechovyn ztorfu: monohr./Ya.M. Korniyenko, A.R. Stepanyuk. - K., 2015. - S. 146. 